\title{
Development of Android-Based Mathematics Learning Game on the Topic of Congruence and Similarity
}

\author{
https://doi.org/10.3991/ijim.v15i09.20723 \\ Abd Qohar $\left.{ }^{(}\right)$, Susiswo, Syaiful Hamzah Nasution, Sapti Wahyuningsih \\ Universitas Negeri Malang, Malang, Indonesia \\ Abd.qohar. fmipa@um.ac.id
}

\begin{abstract}
The rapid development of smartphone technology provides an opportunity for use in mathematics learning. One of the uses of smartphone technology in learning mathematics is mathematics learning games. Research has shown that mathematics learning games are generally only on numbers and are still lacking in geometry. This study aims to develop an android-based mathematics learning game on the geometry topic, i.e., congruence and similarity. This study's research method is the Plomp development method with three stages: preliminary research, the prototyping stage, and the assessment phase. The subjects of this study were 56 seventh-grade students from the Wagir Public Junior High School in Indonesia. Six students participated in small group trials, and $50 \mathrm{stu}-$ dents participated in field trials. The results showed that the Android-based learning game on congruence and similarity had been successfully developed. Experts have validated the game media with a score of 3.36, which shows that the media created are valid. The practicality tests in the small group trial resulted in a score of 3.50, while the field trial resulted in a score of 3.51. The effectiveness tests carried out in the small group trial resulted in a score of 3.36, while the field trial results had a score of 3.38. These results indicate that the learning games developed are practical and useful for use in mathematics learning.
\end{abstract}

Keywords - Mathematics learning game, Android, congruence, and similarity

\section{$1 \quad$ Introduction}

Mathematics is considered a difficult subject by many students in Indonesia. The Program for International Student Assessment in 2018 found that the mathematics abilities of Indonesian students ranked 72 out of 78 countries [1]. This shows that students in Indonesia still experience difficulties in mathematics. Learning innovation is needed to help students overcome difficulties in learning mathematics. One learning innovation that has been widely researched is game-based learning. Studies have found that students who use game-based learning have better learning outcomes [2], games can increase knowledge of rational numbers in students [3], engagement and attitudes [4], and have a positive influence on students [5].

To develop exciting learning games, interactive media are needed. Among several interactive media available, tablets and smartphones are a learning medium that is 
currently being used. The use of tablets in mathematics learning has better results than using PCs [6]. Mobile learning and game-based learning are two critical elements in Technology Enhanced Learning [7]. An excellent interactive learning game can be built with a smartphone because smartphones have advantages over other media, attracting students' attention. The tendency of students to use media will significantly determine the success of learning [8]. Well-designed media can positively impact students [9], and an excellent game-based learning environment supports students' problem-solving development [10].

Smartphone-based mathematics learning games are feasible and meaningful because smartphone digital interactive media is currently part of most children's lives [11]. Teachers' perceptions are excellent regarding using smartphone applications in learning [12]. Learning games have been rapidly developing, and the educational community has started to explore games' effectiveness as a learning tool [13]. Well-designed applications will help children learn math skills [14]. Using technology that is compatible with learning will support implementing this learning [15]; thus, smartphone technology development in learning must be done.

Research on learning using Android and iOS technology, as stated in [16]-[20], obtained very positive results. Android-based games have been widely researched and used in mathematics learning [21]-[23]. However, mathematics learning games on the topic of geometry are still lacking. The majority of android-based learning applications only teach numbers [19]. Congruence and similarity are geometric topics that are considered difficult [24]. Therefore, in this study, an Android-based learning game on congruence and similarity was developed. By using this learning game, students are expected to understand the concept of congruence and similarity, and they will be interested in and love mathematics.

\section{$2 \quad$ Literature Review}

\subsection{Technology in mathematics learning and teaching}

Mathematics is an abstract science. To teach mathematical concepts, teachers are required to design lessons that can bridge these abstract concepts. The use of computer technology to support mathematics learning has been widely researched by experts and has shown that it can improve students' mathematical abilities. This has been researched by [25], which states that computer-based mathematics learning can develop students' cognitive abilities. The use of tablets and computers in learning can improve students' understanding of numbers [26], mathematics literacy [27], cognitive and affective abilities of students [28], [29].

Research conducted by [30] shows that students who received metacognitive instruction in computer-based learning showed a more significant increase in their metacognitive knowledge abilities. The research found [31] that computer-based integrated training can increase student creativity. In addition to these abilities, computer-based learning also increases positive results in terms of conceptual knowledge, procedural knowledge, and problem-solving [32]. The results of the study [9], [14], [33], [34] 
show that the use of IT-based media is a positive influence on learning. Specific reasoning was found to increase with the application of computer-based learning, and mathematical skills improve with applications [14].

\subsection{Android-based learning game}

Learning games are games that aim to learn while playing. Smartphone-based learning games emphasize game content and objectives and aim to attract interest while learning. Therefore, it is necessary to have an exciting and fun educational game for students in the learning process to understand the material provided by educators easily. Android-based learning games mean the game can be run using a smartphone with the Android operating system.

Learning games are currently gaining popularity and are being developed by many experts to support the learning process [35]. Several researchers have conducted studies on mathematics learning using Android-based games. Research on Android-based learning games conducted by [36] succeeded in improving students' critical thinking skills. Android-based games have also been used successfully with good results in programming learning [37], [38], chemistry learning [39], and material learning [40].

\subsection{Congruence and similarity}

Two geometric figures that have the same size and shape are called congruent [41]. If the shape is a triangle, then two triangles are congruent if they have the same three sides and the same three angles. The equal sides and angles may not be in the same position (if there is a turn or a flip), but they are still equal. Two geometric figures with the same shape, but not necessarily the same size, are called similar [41]. Two similar shapes with corresponding angles and corresponding sides have the same length ratio. These concepts are used as a basis for making games to help students master these concepts.

The difficulty students have with congruence and similarity determines whether two shapes are congruent or not and whether the two shapes are similar. Through designed learning games, students are faced with congruent and similar forms. Students are challenged to pair similar forms and congruent forms. With this activity, students will understand the concept of congruence and similarity. Students also enjoy learning mathematics through playing these games.

\section{$3 \quad$ Research Method}

\subsection{Research design}

This study is development research. The development research method used is the Plomp development method with three stages [42]. In the first stage, preliminary research, a literature study is done to explore information and identify what is needed to make mathematics learning games. The second stage is the prototyping stage, which 
entails designing and creating mathematics learning games ready for assessment. The third stage is the assessment phase, which is when the learning games undergo tests, evaluations, and revisions, valid, practical, and useful learning games are created.

\subsection{Research subjects}

The research subjects are mathematics education experts, instructional media experts, teachers, and junior high school students. Educational experts and mathematics learning media experts are lecturers with doctoral education qualifications (doctorate), while teachers and students are from the Wagir Public Junior High School in Indonesia. Fifty-six seventh-grade students participated in the trial. Six of those students consisting of two students with high abilities, two students with moderate abilities, and two students with low abilities, were involved in a small group trial. Meanwhile, the other 50 seventh-grade students participated in field trials.

\subsection{Data collection instrument}

The data in this study were collected using validation sheets and student questionnaires. The validation instrument contents consist of four aspects: accuracy of content, the suitability of images and animation, use of learning games, and clarity of language and symbols. Meanwhile, questionnaires were given to the junior high school students after participating in small group trials or field trials. The questions consist of the aspects of practicality and effectiveness. In terms of practicality, the indicators are as follows: ease of operating the game; clear instructions and information on the game; ease of interaction and learning through the game; suitability of writing; and the attractiveness of images and animations. Meanwhile, the effectiveness indicators are as follows: a problem presentation can help students understand mathematical concepts; games can make learning math fun; games can make students understand mathematics more.

\subsection{Data analysis}

Quantitative data obtained through validation sheets and student questionnaires were analyzed using descriptive statistics, while qualitative data in the form of comments, suggestions, and student work results were used for discussion and revision of game products. The data analysis technique used is explained in the following section.

Validity Test - The validity score of the learning game obtained from each validator was averaged, then the average score data from each validator was used to calculate the overall average. The average validity score obtained was compared to the intervals shown in Table 1 to determine the product's validity level. The validity level interval in Table 1 is based on the questionnaire given to the validators. The questionnaire offered four choices for each indicator: 1) Very Not Suitable, 2) Not Suitable, 3) Suitable, and 4) Very Suitable. From the four choices, a validity level table was compiled, as shown in Table 1. 
Table 1. Validity level

\begin{tabular}{|c|c|}
\hline Average Score of Validity $(\boldsymbol{V} \boldsymbol{r})$ & Validity Level \\
\hline $1 \leq V r<2$ & Invalid \\
\hline $2 \leq V r<3$ & Less Valid \\
\hline $3 \leq V r<4$ & Valid \\
\hline$V r=4$ & Very Valid \\
\hline
\end{tabular}

Practicality and Effectiveness Test - Implementing small group trials and field trials produced practicality and effectiveness scores. The results for practicality and effectiveness were obtained from the questionnaire given to the students. The questionnaire offered four answer choices for each indicator: 1) Very Not Suitable, 2) Not Suitable, 3) Suitable, 4) Very Suitable.

The learning game's practicality was obtained from each student who participated in the trial, and the average was calculated. The average practicality score results were compared with the practicality level intervals shown in Table 2 to determine the game products' practicality level.

Table 2. Practicality level

\begin{tabular}{|c|c|}
\hline Average Score of Practicality $(\mathbf{P r})$ & Practicality Level \\
\hline $1 \leq \operatorname{Pr}<2$ & Impractical \\
\hline $2 \leq \operatorname{Pr} r 3$ & Less Practical \\
\hline $3 \leq \operatorname{Pr}<4$ & Practical \\
\hline $\operatorname{Pr}=4$ & Very Practical \\
\hline
\end{tabular}

The learning game's effectiveness ranked by each student who participated in the trial was also calculated as an average. The average effectiveness score results were compared with the intervals of the effectiveness levels shown in Table 3 to determine the game products' level of effectiveness.

Table 3. Effectiveness level

\begin{tabular}{|c|c|}
\hline Average Score of Effectiveness (Ef) & Effectiveness Level \\
\hline $1 \leq \mathrm{Ef}<2$ & Ineffective \\
\hline $2 \leq \mathrm{Ef}<3$ & Less effective \\
\hline $3 \leq \mathrm{Ef}<4$ & Effective \\
\hline $\mathrm{Ef}=4$ & Very effective \\
\hline
\end{tabular}

The game application developed in this study is named KOKA, which stands for Indonesian Kongruen (means congruence) and Kesebangunan (means similarity). The early development learning game is KOKA version 1 ; the validation, trial, and revision processes are carried out to obtain KOKA version 4 (final version). The procedures of the validation, trial, and revision processes can be seen in the diagram in Figure 1. 


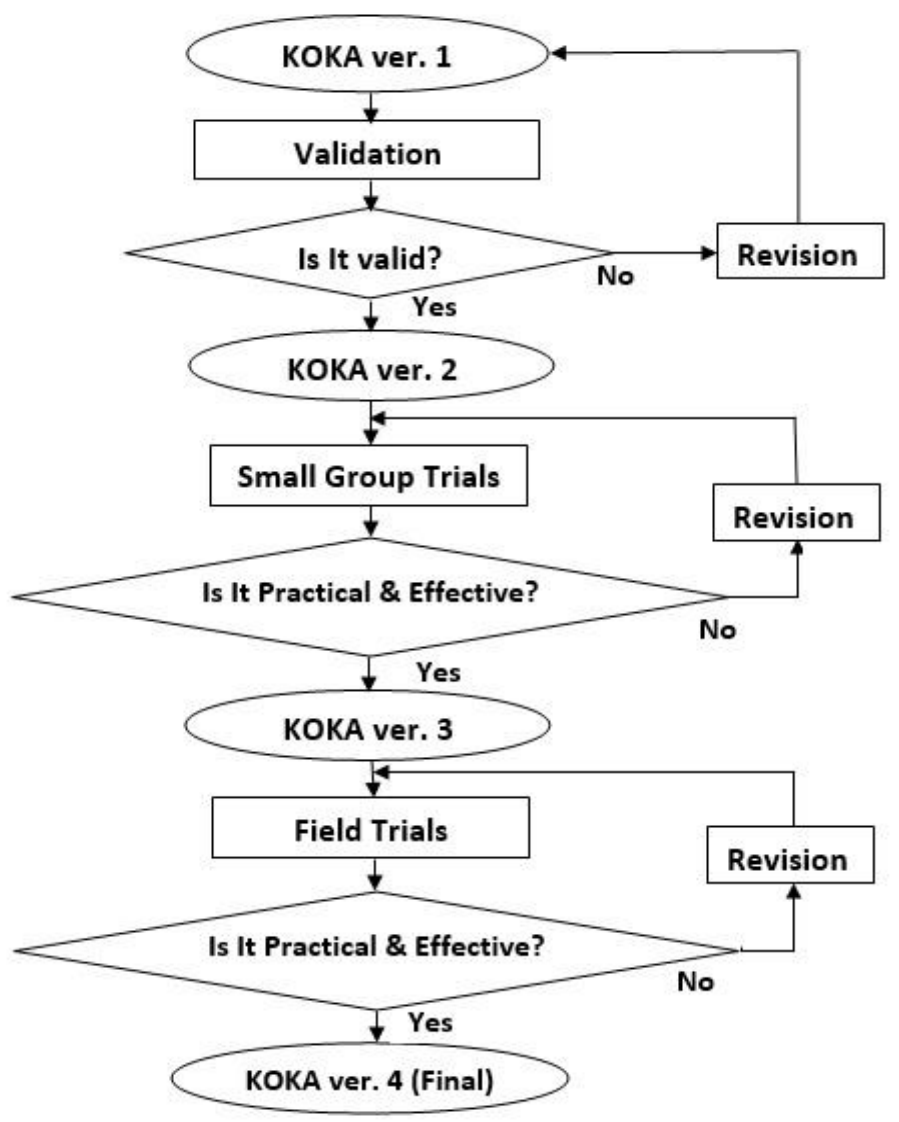

Fig. 1. Procedures at the validation, trial, and revision process

\section{$4 \quad$ Results}

This study used the Plomp model consisting of three stages: preliminary research, prototyping stage, and assessment phase. Each stage is described as follows.

\subsection{Preliminary research}

The initial investigation stage identified and assessed what was needed to develop the product. Identification and study were made on matters related to product development, namely A) Core Competencies and Basic Competencies in Junior High School Mathematics, which was was obtained from the 2013 Indonesian national curriculum; (B) Android-based games that are already circulating in the market, for example, games available in the Play Store, especially math learning games. This study found that mathematics learning games that were researched and those in the Play Store were generally games about numbers and number operations. Meanwhile, games about two- 
dimensional figures, congruence, and similarity, were lacking, so it needed to be developed; (C) characteristics of technology-assisted mathematics learning; (D) characteristics of junior high school students: In addition to studying theories, the researcher also spoke with junior high school mathematics teachers about the learning games to be developed.

\subsection{Prototyping stage}

At the prototype stage, the steps are to design and make a game. In-game design activities, creators create a storyboard and determine the flow of the game. After making a game design, the next stage is making the game. The researcher makes a color background for the game, determines and includes the sound background, writes game stories, and creates games using Adobe Flash CS 6 and Adobe Illustrator CS 6 software. The following describes the results of the game-making steps that have been completed. The pictures are examples of screenshots of the Android-based learning games that were made.

The game's initial display is in the form of the Main menu; after entering the Main menu, the player enters at level 1. An example of the level 1 game display is shown in Figure 2. At this level, students are shown two groups of pictures divided into left and right parts. The challenge is to find pictures of the same shape and size (congruent) between the pictures on the left and the pictures. The procedure shifts the image (drag) from the left image to the appropriate right image. If the picture's choice is correct, it will receive a score, but if it is not correct, it will get a reduced score. The scoring rules apply to all levels.

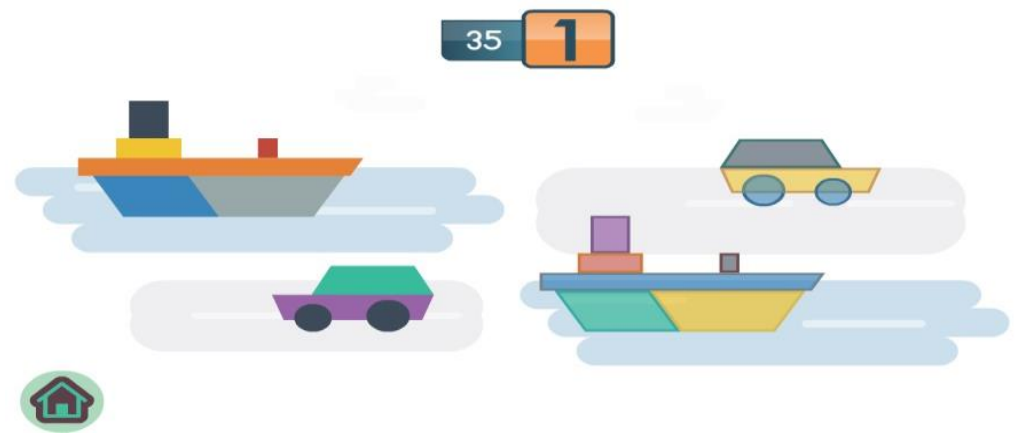

Fig. 2. An example of the game display level 1

After level 1 is completed, the player continues to level 2. At level 2, students are shown two groups of flat buildings of various shapes. An example of the level 2 game display is shown in Figure 3. Students determine which flat buildings are congruent by shifting (dragging) from left to right. After level 2 is completed, the player continues to level 3. 


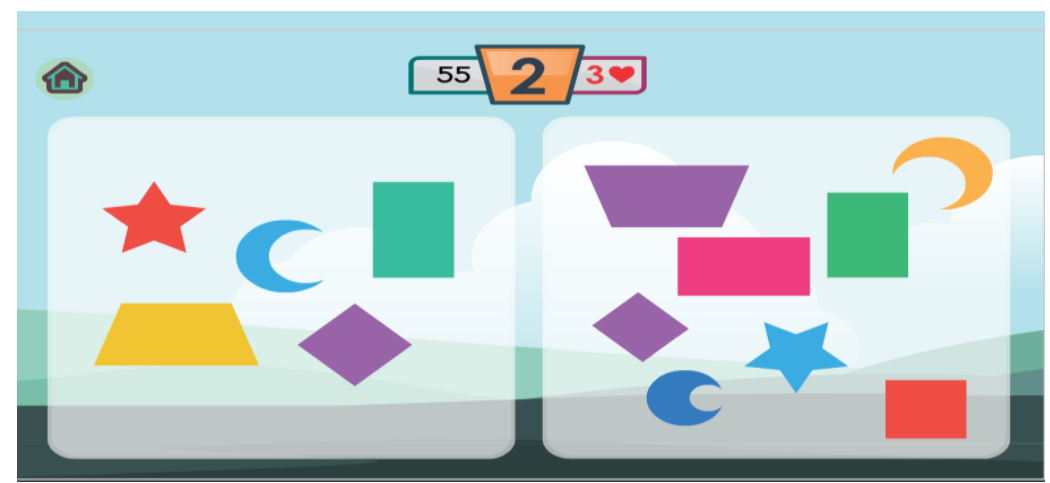

Fig. 3. An example of the game display level 2

An example of the level 3 game display is shown in Figure 4. At level 3, the images displayed start to become more formal, using signs indicating that the two shapes are congruent. If students successfully finish level 3, they will go to level 4, which is the final level. At level 4, students are shown pictures with standard sizes. There are different display problems in level 4. An example of the level 4 game display is shown in Figure 5. The image presented is in the form of flat shapes with sizes according to the existing grid. If all levels are passed or if time is up, the student receives the final score. The maximum score of this game is 1000 .

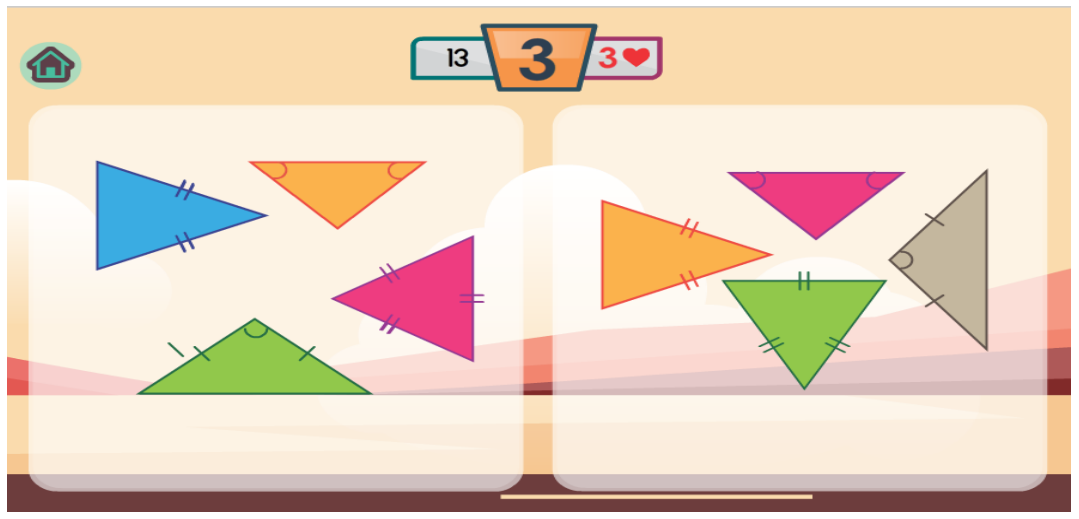

Fig. 4. An example of the game display level 3 


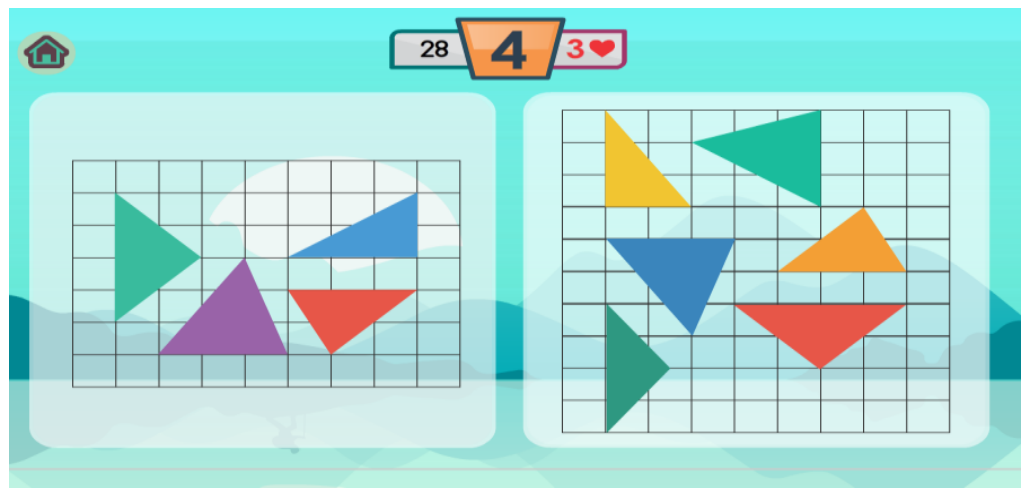

Fig. 5. An example of the game display level 4

\subsection{Assessment phase}

A validation test, trial, and revision process were carried out on the game in the assessment phase. Validation was done by mathematics education experts, computer-assisted instructional media experts, and junior high school teachers, while the small group trials and field trials were conducted on junior high school students. The results of the validation, comments, and suggestions from the validators, teachers, and students were used as a reference for making revisions.

Validation was done by providing the learning game program and validation sheets to the experts. The media validity test was examined from the aspects of learning media, images and animation, use of learning media, and language and symbols. The validation questionnaire used a scale of 1-4. The quantitative data from the validation test results are presented in Table 4. 
Paper-Development of Android-Based Mathematics Learning Game on the Topic of Congruence..

Table 4. Result of the KOKA Game Validity by experts

\begin{tabular}{|c|c|c|}
\hline $\begin{array}{l}\text { Assessment } \\
\text { Aspects }\end{array}$ & Description & $\begin{array}{l}\text { Average Vali- } \\
\text { dation Score }\end{array}$ \\
\hline \multirow{5}{*}{$\begin{array}{l}\text { Learning Media } \\
\text { Content }\end{array}$} & Learning game media can help students learn mathematics & 3.67 \\
\hline & $\begin{array}{l}\text { Learning game media can help students build understanding inde- } \\
\text { pendently }\end{array}$ & 3.33 \\
\hline & Learning game media enable students to like mathematics & 3.33 \\
\hline & $\begin{array}{l}\text { The activities provided enable a positive interaction between students and } \\
\text { learning media }\end{array}$ & 3.67 \\
\hline & $\begin{array}{l}\text { Activities contained in the learning media are following the learning ob- } \\
\text { jectives. }\end{array}$ & 3.33 \\
\hline \multirow{4}{*}{$\begin{array}{l}\text { Images and Ani- } \\
\text { mations }\end{array}$} & $\begin{array}{l}\text { Learning media is accompanied by images and animations that are fol- } \\
\text { lowing the material or concept of similarity and congruence }\end{array}$ & 3.67 \\
\hline & The images and animations used can clarify the learning material & 3.67 \\
\hline & The images and animations are attractive & 3.50 \\
\hline & $\begin{array}{l}\text { The images and animations presented are appropriate to Junior High } \\
\text { School students }\end{array}$ & 3.33 \\
\hline \multirow{4}{*}{$\begin{array}{l}\text { Learning Media } \\
\text { Usefulness }\end{array}$} & It can be used to assist students in achieving learning goals & 3.33 \\
\hline & Students can use it to learn independently & 3.00 \\
\hline & It can be used as a support for learning mathematics in schools & 3.33 \\
\hline & Can encourage students to be more active in the learning process & 3.33 \\
\hline \multirow{4}{*}{$\begin{array}{l}\text { Language and } \\
\text { Symbols }\end{array}$} & The language used is communicative & 3.33 \\
\hline & $\begin{array}{l}\text { The terms and symbols used are appropriate and can be understood by } \\
\text { students }\end{array}$ & 3.00 \\
\hline & The display color, font type, the font size used are attractive to students & 3.00 \\
\hline & Average & 3,36 \\
\hline
\end{tabular}

Table 4 shows that the overall average value of the media validation was 3.36. Based on Table 1, the learning media presented was categorized as valid so that the learning media could be used on students. However, a little revision according to the comments/suggestions given by the validators was still needed. In addition to the quantitative data, media validation also produced qualitative data in comments and suggestions, and recommendations from the validators about the media being developed. The qualitative data are as follows:

\section{Comments \& Suggestions:}

- There needs to be a little improvement in some steps in implementing the media.

- The image in the game cannot be rotated when paired with a similar image. It should be corrected.

- The orientation of the image should be varied. For example, in the image at level 1, the image of the ship is reversed.

- Need to continue to the next level (additional level).

- Need to add material before students get into the game. For example, show the definition of similarity.

The KOKA ver.1 learning game was then revised based on comments and suggestions from the validators. After the revision was complete, the KOKA ver.2 game was ready for small group trials on seventh-grade junior high school students. 
The Trial Process was conducted after the learning game was revised during the validation process and declared valid. The trial was done in two stages, small group trials and field trials. Small group trials were conducted on six seventh-grade students with varying math abilities. In this small group trial, the KOKA ver.2 game was tested, and its practicality and effectiveness were obtained. The results of the small group trials' practicality and effectiveness can be seen in Table 5, column 2 . Table 5 shows that the average score of practicality in the small group trial was 3.50, while the average score of effectiveness was 3.36. Table 2 and Table 3 indicate that the KOKA ver. 2 game is included in the practical category and is effective in small group trials. However, the KOKA ver. 2 game underwent a small revision based on students' input, and this process resulted in the KOKA ver.3 game used for field trials.

Field trials were conducted on 50 seventh-grade students. The trial process was done useful KOKA ver.3 game to obtain practicality and effectiveness data. The results on the field trials' practicality and effectiveness are presented in Table 5, column 3.

Table 5. Data of students' response questionnaire result

\begin{tabular}{|c|c|c|}
\hline Description & \begin{tabular}{|c|} 
Average Score of \\
Small Group \\
Trial
\end{tabular} & $\begin{array}{l}\text { Average Score } \\
\text { of Field Trial }\end{array}$ \\
\hline \multicolumn{3}{|l|}{ Practicality Aspects } \\
\hline Mathematics learning game is easy for me to operate & 3.47 & 3.50 \\
\hline $\begin{array}{l}\text { The instructions and information presented are easy for me to under- } \\
\text { stand }\end{array}$ & 3.37 & 3.38 \\
\hline Learning games allow me to interact and learn math & 3.78 & 3.78 \\
\hline $\begin{array}{l}\text { The writing, images and animations used in the learning media are fol- } \\
\text { lowing the learning material provided }\end{array}$ & 3.47 & 3.46 \\
\hline The use of images and animation in learning media is attractive & 3.44 & 3.44 \\
\hline Average practicality score & 3.50 & 3.51 \\
\hline \multicolumn{3}{|l|}{ Effectiveness Aspects } \\
\hline $\begin{array}{l}\text { The problem presented in the mathematics learning game helps me un- } \\
\text { derstand mathematics concepts }\end{array}$ & 3.47 & 3.46 \\
\hline $\begin{array}{l}\text { I love to learn mathematics through this learning game because it is at- } \\
\text { tractive }\end{array}$ & 3.39 & 3.44 \\
\hline This learning game makes me love mathematics & 3.29 & 3.24 \\
\hline This learning game makes me want to understand mathematics further & 3.28 & 3.38 \\
\hline Average effectiveness score & 3.36 & 3.38 \\
\hline
\end{tabular}

Table 5 shows that the average score of practicality in the field trial was 3.51 , while the average score of effectiveness was 3.38. Table 2 and Table 3 indicate that the KOKA ver.3 game is included in the practical category and is useful in field trials. After completing the trial, students provided comments and suggestions. In general, students provided good comments on the learning games. Some comments and suggestions from students are as follows: 


\section{Comments \& Suggestions:}

- Lives are added, for example, ten hearts, and the in-game time provided needs to be longer.

- The game is beautiful. I have become more careful in mathematics.

- I will learn more.

- The game needs additional time.

- All is well.

- Always concentrate and think faster.

- All is well, but there are a few bugs in the game.

The KOKA ver.3 learning game was then revised based on comments and suggestions from the students. After the revision was complete, the KOKA ver.4 (final version) learning game was ready for junior high school students.

\section{Discussion}

The Android-based mathematics learning game called KOKA is the product of the development in this research. The learning media developed is in the form of 1 Application Package File (.apk), namely Koka.apk. The expert validation test (see Table 4) states that the games that have been developed are valid. This result means that learning game content, animation, usefulness, language, and symbols follow the theory of making learning games. This study's results align with research [43], which states that a good game combines cognitive, motivation, and affective factors. To start the game, the user must open the Koka Application installed on the Android smartphone. Several pages will be displayed, including the main menu page, instruction page, and the learning game page. Generally, there are two groups on the learning game page, the congruence game and the similarity game. Each group consists of four levels, starting from the easy one to the difficult one.

The practicality test results (see Table 5) show that the games made are in the practical category. These results indicate that the games made are easy to operate, the instructions are easy to understand, interactive, attractive, and following the learning topic. The learning games made in this study aim to make students understand the concepts of congruence and similarity. The elements of the game are considered, namely the score, the winners, and the losers. With these elements, students become more enthusiastic because the individual factors are also considered [44]. Instructions and explanations are also made complete so that students can make connections between game terminology and mathematical terminology [45].

Furthermore, [46] stated the need for constructivist principles in learning games. In this KOKA game, a constructivist element is present in each level of the game. At the initial level, students are given easy and informal games. This is important for learning because students are faced with activities to see real pictures [47]. At the following levels, the difficulty increases and becomes more formal. This gradually constructs the concept of congruence and similarity while playing the games. Besides, [46] also 
suggests that students have an element of fun. With this element, students will feel curiosity and can get satisfaction and pride.

Playing games can also foster motivation, including motivation to get high scores. To obtain a high score, students must gradually understand the material so that the concept construction process can be carried out following the learning objectives. Students try to get a high game score in the KOKA game while learning the concepts of congruence and similarity. According to [48], game-based learning is beneficial in the learning process because games are emotionally attractive. Physically active lessons can be beneficial for learning mathematics [49]. These results are following the research that states that IT-based learning media can have a positive impact on children [9], [50] and can help them learn essential math skills [14].

The effectiveness test results (see Table 5) show that the KOKA game is included in the effective category. These results indicate that this learning game can help students learn mathematics. This learning game can also make students love math. These results follow research [2], which states that game-based learning can increase learning outcomes, interests, and positive emotional experiences. In learning games, fun elements and educational concepts can be combined to increase student motivation and engagement [51]. In the KOKA game, the fun element is in the colorful wake-up images and the score at the end of the game. The faster and more precise it is, the higher the score so that the misery can be obtained. In addition to having fun, [52] also stated that learning games had been proven to be a tool that effectively improves teaching and learning, and teachers can build a pleasant environment through games. Through the KOKA game, students can experience victory; therefore, change, challenge, and enjoyment can characterize the entire learning process. This activity is the main reason for the attractiveness of learning games to students. This finding is in line with [53], which states that using digital math games can improve behavior in the learning process to be interested in learning.

\section{$6 \quad$ Limitations and Future Studies}

After the implementation of this development research, there are several limitations to the learning games that have been made, namely:

- KOKA learning games can only be operated on Android-based smartphones

- KOKA learning games are only for learning mathematics on congruence and similarity topics

- The effectiveness of learning games is only seen from the results of the questionnaire.

From these limitations, further research must study the use of learning games on other mathematics or geometry topics. Research also needs to be done on the congruence and similarity topics and adding content and other more varied contexts. The effectiveness of learning games also needs to be seen through other instruments. The effect of android-based mathematics learning games on other abilities, such as critical and creative thinking, also needs further investigation. 


\section{Conclusion}

An Android-based learning game media on the topic of congruence and similarity named KOKA has been successfully developed. The game media developed has been validated and obtained media validation results with a score of 3.36, which indicates that the media is valid. The practicality test results in the KOKA learning game were obtained from the student questionnaires' results, which received a score of 3.50 in the small group trial and 3.51 in the field trial. In the KOKA learning game's effectiveness test, the score was 3.36 in the small group trial and 3.38 in the field trial. This shows that the media developed is both practical and useful. From the explanation of the validity, practicality, and effectiveness tests, the learning games developed can be used to learn the topic of congruence and similarity.

An important finding in this study is that students become excited about learning mathematics using Android-based learning games. Students who initially perceive mathematics as a scary subject, their perceptions change after learning using this game. This finding shows that other researchers can further develop the learning approach through games. This learning game can be used as a reference to be developed in other topics. For teachers and students, especially at the junior high school level, the learning games can be used as an alternative medium to learn about congruence and similarity so that learning becomes fun.

\section{Acknowledgement}

We would like to thank Direktorat Riset dan Pengabdian Masyarakat (DRPM) Kemenristek/BRIN Republik Indonesia for funding this research.

\section{$9 \quad$ References}

[1] A. Schleicher, "PISA 2018: insights and interpretations," OECD Publ., p. 64, 2019, [Online]. Available: https://www.oecd.org/pisa/PISA 2018 Insights and Interpreta-tions FINAL PDF.pdf. https://doi.org/10.1787/9789264301603-en

[2] M. Taub, R. Sawyer, A. Smith, J. Rowe, R. Azevedo, and J. Lester, "The agency effect: The impact of student agency on learning, emotions, and problem-solving behaviors in a gamebased learning environment," Comput. Educ., 2020, https://doi.org/10.1016/j.compedu. 2019.103781

[3] K. Kiili, K. Moeller, and M. Ninaus, "Evaluating the effectiveness of a game-based rational number training - In-game metrics as learning indicators," Comput. Educ., 2018, https://doi.org/10.1016/j.compedu.2018.01.012

[4] M. Kalogiannakis and S. Papadakis, "Evaluating the effectiveness of a game-based learning approach in modifying students' behavioral outcomes and competence, in an introductory programming course. A case study in Greece," Int. J. Teach. Case Stud., vol. 10, no. 3, p. 235, 2019, https://doi.org/10.1504/ijtcs.2019.10024369

[5] J. A. Ruipérez-Valiente and Y. J. Kim, "Effects of solo vs. collaborative play in a digital learning game on geometry: Results from a K12 experiment," Comput. Educ., vol. 159, no. October 2019, 2020, https://doi.org/10.1016/j.compedu.2020.104008 
[6] S. Papadakis, M. Kalogiannakis, and N. Zaranis, "Comparing Tablets and PCs in teaching Mathematics: An attempt to improve Mathematics Competence in Early Childhood Education," Presch. Prim. Educ., vol. 4, no. 2, p. 241, 2016, https://doi.org/10.12681/ppej.8779

[7] L. Bennis and S. Amali, "From learning game to adaptive ubiquitous game-based learning," Int. J. Emerg. Technol. Learn., vol. 14, no. 16, pp. 55-65, 2019, https://doi.org/10.3991/ ijet.v14i16.10701

[8] J. P. Byrnes and B. A. Wasik, "Factors predictive of mathematics achievement in kindergarten, first and third grades: An opportunity-propensity analysis," Contemp. Educ. Psychol., vol. 34, no. 2, pp. 167-183, 2009, https://doi.org/10.1016/i.cedpsych.2009.01.002

[9] D. L. G. Borzekowski, "A quasi-experiment examining the impact of educational cartoons on Tanzanian children,” J. Appl. Dev. Psychol., vol. 54, no. March 2017, pp. 53-59, 2018, https://doi.org/10.1016/j.appdev.2017.11.007

[10] B. Brezovszky et al., "Effects of a mathematics game-based learning environment on primary school students' adaptive number knowledge," Comput. Educ., 2019, doi: 10.1016/j.compedu.2018.09.011.

[11] E. A. Wartella et al., Digital media use by young children: Learning, effects, and health outcomes. Elsevier Inc., 2018.

[12] M. A. Abugohar, K. Yunus, and R. A. Rashid, "Smartphone applications as a teaching technique for enhancing tertiary learners' speaking skills: Perceptions and practices," Int. J. Emerg. Technol. Learn., vol. 14, no. 9, pp. 74-92, 2019, https://doi.org/10.3991/ijet. v14i09.10375

[13] D. N. Karagiorgas and S. Niemann, "Gamification and Game-Based Learning," J. Educ. Technol. Syst., 2017, doi: 10.1177/0047239516665105.

[14] K. Schenke et al., 'Does 'Measure Up!' measure up? Evaluation of an iPad app to teach preschoolers measurement concepts," Comput. Educ., vol. 146, p. 103749, 2020, https:// doi.org/10.1016/j.compedu.2019.103749

[15] A. W. McCulloch, K. Hollebrands, H. Lee, T. Harrison, and A. Mutlu, "Factors that influence secondary mathematics teachers' integration of technology in mathematics lessons," Comput. Educ., 2018, https://doi.org/10.1016/j.compedu.2018.04.008

[16] M. Murdiono, Suyato, E. N. Rahmawati, and M. A. Aziz, "Developing an android-based mobile application for civic education learning,” Int. J. Interact. Mob. Technol., vol. 14, no. 16, pp. 180-193, 2020, https://doi.org/10.3991/ijim.v14i16.14967

[17] A. Huda, N. Azhar, Almasri, K. Anshari, and S. Hartanto, "Practicality and effectiveness test of graphic design learning media based on android," Int. J. Inter-act. Mob. Technol., vol. 14, no. 4, pp. 192-203, 2020, https://doi.org/10.3991/ijim.v14i04.12737

[18] M. Friedl, M. Ebner, and M. Ebner, "Mobile Learning Applications for An-droid und iOS for German Language Acquisition based on Learning Analytics Measurements," Int. J. Learn. Anal. Artif. Intell. Educ., vol. 2, no. 1, p. 4, 2020, https://doi.org/10.3991/ ijai.v2i1.12317

[19] S. Papadakis, M. Kalogiannakis, and N. Zaranis, "Educational apps from the Android Google Play for Greek preschoolers: A systematic review," Comput. Educ., vol. 116, pp. 139-160, 2018, https://doi.org/10.1016/j.compedu.2017.09.007

[20] A. C. Sari, A. M. Fadillah, J. Jonathan, and M. R. D. Prabowo, "Interactive gamification learning media application for blind children using android smartphone in Indonesia," Procedia Comput. Sci., vol. 157, pp. 589-595, 2019, https://doi.org/10.1016/j.procs.2019. $\underline{09.018}$

[21] P. Juric, M. B. Bakaric, and M. Matetic, "Design and implementation of anonymized social network-based mobile game system for learning mathematics," Int. J. Emerg. Technol. Learn., vol. 13, no. 12, pp. 83-98, 2018, https://doi.org/10.3991/ijet.v13i12.8762 
[22] Y. Tazouti, S. Boulaknadel, and Y. Fakhri, "JeuTICE: An arabic serious game to enhance mathematics skills of young children," Int. J. Emerg. Technol. Learn., vol. 14, no. 22, pp. 252-265, 2019, https://doi.org/10.3991/ijet.v14i22.11119

[23] W. Widyasari, H. Sutopo, and M. Agustian, "QR code-based learning development: Accessing math game for children learning enhancement,” Int. J. Interact. Mob. Technol., vol. 13, no. 11, pp. 111-124, 2019, https://doi.org/10.3991/ijim.v13i11.10976

[24] S. Dündar and N. Gündüz, "Justification for the subject of congruence and similarity in the context of daily life and conceptual knowledge," J. Math. Educ., vol. 8, no. 1, pp. 35-54, 2017, doi: 10.22342/jme.8.1.3256.35-54.

[25] S. M. M. de Mooij, N. Z. Kirkham, M. E. J. Raijmakers, H. L. J. van der Maas, and I. Dumontheil, "Should online math learning environments be tailored to individuals' cognitive profiles?” J. Exp. Child Psychol., vol. 191, p. 104730, 2020, https://doi.org/10.1016/ i.jecp.2019.104730

[26] S. Papadakis, M. Kalogiannakis, and N. Zaranis, "The effectiveness of computer and tablet assisted intervention in early childhood students' understanding of numbers. An empirical study conducted in Greece," Educ. Inf. Technol., vol. 23, no. 5, pp. 1849-1871, 2018, https://doi.org/10.1007/s10639-018-9693-7

[27] P. Dorouka, S. Papadakis, and M. Kalogiannakis, "Tablets and apps for promoting robotics, mathematics, STEM education and literacy in early childhood education," Int. J. Mob. Learn. Organ., vol. 14, no. 2, pp. 255-274, 2020, doi: 10.1504/IJMLO.2020.106179. https://doi.org/10.1504/ijmlo.2020.10026334

[28] H. Jeong, C. E. Hmelo-Silver, and K. Jo, "Ten years of Computer-Supported Collaborative Learning: A meta-analysis of CSCL in STEM education during 2005-2014,” Educ. Res. Rev., vol. 28, no. June, p. 100284, 2019, https://doi.org/10.1016/j.edurev.2019.100284

[29] W. Kozakowski, "Moving the classroom to the computer lab: Can online learning with inperson support improve outcomes in community colleges?" Econ. Educ. Rev., vol. 70, no. March, pp. 159-172, 2019, https://doi.org/10.1016/j.econedurev.2019.03.004

[30] T. R. Kautzmann and P. A. Jaques, "Effects of adaptive training on meta-cognitive knowledge monitoring ability in computer-based learning," Comput. Educ., vol. 129, pp. 92-105, 2019, https://doi.org/10.1016/j.compedu.2018.10.017

[31] Y. chu Yeh, E. M. Rega, and S. Y. Chen, "Enhancing creativity through aesthetics-integrated computer-based training: The effectiveness of a FACE approach and exploration of moderators," Comput. Educ., vol. 139, no. 64, pp. 48-64, 2019, https://doi.org/10. 1016/j.compedu.2019.05.007

[32] M. Volk, M. Cotič, M. Zajc, and A. Istenic Starcic, "Tablet-based cross-curricular maths vs. traditional maths classroom practice for higher-order learning outcomes," Comput. Educ., vol. 114, pp. 1-23, 2017, https://doi.org/10.1016/j.compedu.2017.06.004.

[33] R. H. Morse, “Computer Uses in Secondary Science Education," in ERIC Di-gests, 1991, pp. 1-6.

[34] S. Papadakis, "Robots and Robotics Kits for Early Childhood and First School Age," Int. J. Interact. Mob. Technol., vol. 14, no. 18, pp. 34-56, 2020, https://doi.org/10.3991/ijim. v14i18.16631

[35] A. Qohar, Susiswo, S. H. Nasution, and A. M. G. Adem, "Android-Based Mathematics Learning Games That are Interesting for Junior High School Stu-dents," in Journal of Physics: Conference Series, 2019, vol. 1227, no. 1, https://doi.org/10.1088/1742-6596/1227/ 1/012013.

[36] S. Lestari, L. Agung, and A. Musadad, "Android Based Adventure Games to Enhance Vocational High School Students' Critical Thinking Skills,” pp. 3-8, 2019, https://doi.org/ $\underline{10.4108 / \text { eai.27-4-2019.2286917. }}$. 
[37] T. Jordine, Y. Liang, and E. Ihler, “A Mobile Device Based Serious Gaming Approach for Teaching and Learning Java Programming Approach for Teaching and Learning Java Programming," vol. 9, no. 1, pp. 53-59, 2015.

[38] S. Papadakis, "Evaluating a game-development approach to teach introductory programming concepts in secondary education,” Int. J. Technol. Enhanc. Learn., vol. 12, no. 2, pp. 127-145, 2020, https://doi.org/10.1504/ijtel.2020.106282

[39] M. Nazar, R. I. C. Putri, and K. Puspita, "Developing an android-based game for chemistry learners and its usability assessment," Int. J. Interact. Mob. Technol., vol. 14, no. 15, pp. 111-124, 2020, https://doi.org/10.3991/ijim.v14i15.14351

[40] S. Sari, R. Anjani, I. Farida, and M. A. Ramdhani, "Using Android-Based Educational Game for Learning Colloid Material,” J. Phys. Conf. Ser., vol. 895, no. 1, 2017, https://doi.org/ 10.1088/1742-6596/895/1/012012

[41] G. L. Musser, W. F. Burger, and B. E. Peterson, Mathematics for Elementary Teachers, A Contemporary Approach, 9th ed. New Jersey: John Wiley \& Sons, Inc., 2011.

[42] T. Plomp and N. Nieveen, "An Introduction to Educational Design Re-search," Proc. Semin. Conduct. East China Norm. Univ. Shanghai Univ. P.R. China, 2007, [Online]. Available: https://research.utwente.nl/files/14472302/Introduction_20to_20education_20design_20research.pdf

[43] J. L. Plass, B. D. Homer, and C. K. Kinzer, "Foundations of Game-Based Learning," Educ. Psychol., 2015, doi: 10.1080/00461520.2015.1122533.

[44] M. E. Sheppard and R. Wieman, "What do teachers need? Math and special education teacher educators' perceptions of essential teacher knowledge and experience," J. Math. Behav., vol. 59, no. July 2019, p. 100798, 2020, https://doi.org/10.1016/j.jmathb.2020. $\underline{100798}$

[45] H. F. O’Neil, G. K. W. K. Chung, D. Kerr, T. P. Vendlinski, R. E. Buschang, and R. E. Mayer, "Adding self-explanation prompts to an educational computer game," Comput. $\mathrm{Hu}-$ man Behav., vol. 30, pp. 23-28, 2014, https://doi.org/10.1016/j.chb.2013.07.025

[46] J. Hense and H. Mandl, "Learning in or with games? Quality criteria for digital learning games from the perspectives of learning, emotion, and motivation theory," 2012.

[47] A. J. Baroody, The Use of Concrete Experiences in Early Childhood Mathematics Instruction, 1st ed., vol. 53. Elsevier Inc., 2017.

[48] M. Ninaus et al., "Increased emotional engagement in game-based learning - A machine learning approach on facial emotion detection data," Comput. Educ., 2019, https://doi. org/10.1016/i.compedu.2019.103641

[49] M. Vetter, H. T. O'Connor, N. O'Dwyer, J. Chau, and R. Orr, “'Maths on the move': Effectiveness of physically-active lessons for learning maths and increasing physical activity in primary school students," J. Sci. Med. Sport, 2020, https://doi.org/10.1016/j.jsams.2019. 12.019

[50] J. Hamari, D. J. Shernoff, E. Rowe, B. Coller, J. Asbell-Clarke, and T. Ed-wards, "Challenging games help students learn: An empirical study on engagement, flow and immersion in game-based learning," Comput. Human Behav., 2016, https://doi.org/10.1016/j.chb.2015. $\underline{07.045}$

[51] R. Al-Azawi, F. Al-Faliti, and M. Al-Blushi, "Educational Gamification Vs. Game Based Learning: Comparative Study,” Int. J. Innov. Manag. Technol., 2016, https://doi.org/10. 18178/ijimt.2016.7.4.659

[52] Y. C. Chang, H. Y. Peng, and H. C. Chao, "Examining the effects of learning motivation and of course design in an instructional simulation game," Interact. Learn. Environ., 2010, doi: 10.1080/10494820802574270. 
[53] L. Rodrigues and J. Brancher, "Procedurally generating a digital math game's levels: Does it impact players' in-game behavior?" Entertain. Comput., vol. 32, no. May, p. 100325, 2019, https://doi.org/10.1016/j.entcom.2019.100325

\section{Authors}

Abd Qohar is an associate professor at Faculty Science, and Mathematics, Universitas Negeri Malang, Indonesia. His research interests include mathematics education; IT based learning, and curriculum development. Email: abd.qohar.fmipa@um.ac.id

Susiswo is an associate professor at Faculty Science, and Mathematics, Universitas Negeri Malang, Indonesia. His research interests include mathematics education. Email: susiswo.fmipa@um.ac.id

Syaiful Hamzah Nasution is a senior lecturer at Faculty Science, and Mathematics, Universitas Negeri Malang, Indonesia. His research interests include computer-based mathematics learning and mathematics education. Email: syaiful.hamzah.fmipa@um. $\underline{\text { ac.id }}$

Sapti Wahyuningsih is an associate professor at Faculty Science, and Mathematics, Universitas Negeri Malang, Indonesia. Her research interests include applied mathematics and disruptive learning innovations in higher education. Email: sapti.wahyuningsih.fmipa@um.ac.id

Article submitted 2020-12-22. Resubmitted 2021-02-07. Final acceptance 2021-02-08. Final version published as submitted by the authors. 